\title{
Influence of Copper Addition on Sigma Phase Precipitation during Hot Deformation of Duplex Steel
}

\author{
Grzegorz Stradomski ${ }^{1, *}$,, Arkadiusz Szarek ${ }^{2}$ and Dariusz Rydz ${ }^{1}$ \\ 1 Faculty of Production Engineering and Materials Technology, Czestochowa University of Technology, \\ 19 Armii Krajowej Av. 42-200 Czestochowa, Poland; imitm@wip.pcz.pl \\ 2 Faculty of Mechanical Engineering and Computer Science, Czestochowa University of Technology, \\ 21 Armii Krajowej Av. 42-200 Czestochowa, Poland; itm@itm.pcz.pl \\ * Correspondence: gstradomski@wip.pcz.pl; Tel.: +48-3-4325-0782
}

Received: 13 March 2020; Accepted: 2 April 2020; Published: 3 April 2020

\begin{abstract}
The paper presents an experimental study on microstructure changes in duplex steel after hot deformation. Duplex steels and cast steels are characterized by a multiphase microstructure. They are relatively new materials with great contributions to the many fields of industries. Due to the fact of deforming two different phase austenite and ferrite those materials have a complex plasticity. This work is a continuation and complementation of previous works and is a significant supplement to information presented in them. The article concerns precipitation phenomena and changes in the microstructure of two grades of ferritic-austenitic steels: X2CrNiMoN25-7-4 and X2CrNiMoCuN25-6-3. Those steels have a very similar chemical composition, differing by only $2.5 \%$ copper content. An important aspect presented in the work is we observed that adding $2.5 \%$ copper prevented precipitation of the destructive sigma phase during the hot deformation.
\end{abstract}

Keywords: duplex steel; hot deformation; sigma phase; plasticity; microstructure; influence of copper addition

\section{Introduction}

Steels and other iron alloys are very well known as construction materials, are widely-used and in the near future this will not change. Among the resistant-to-corrosion steels (Figure 1) and cast steels, the most modern and dynamically developing group are ferritic-austenitic alloys [1-19]. They are commonly known as duplex. The genesis and development of duplex steels is associated with the appearance of stainless steels in the early twentieth century. In Sheffield (UK), it was found that the addition of chromium at approximately 13\% causes electrochemical corrosion resistance [6]. The main application area of duplex steels and cast steels are structures and elements exposed to high loads and environments conducive to stress, pitting or crevice corrosion. For most resistant-to-corrosion steel grades, local corrosion (pitting, crevice, intergranular) is much more dangerous than general corrosion. Hence, modifications and optimization of chemical compositions and microstructures are applied. The development of the special ferritic-austenitic steels group allows us to increase the durability of elements exposed to erosive and corrosive wear or the exploitation of deeply lying, highly sulfurized gas and oil deposits [1-5,7-21].

Taking under consideration such conditions, duplex steels and cast steels with a comparable proportion of the basic phases-ferrite and austenite-present a better set of mechanical properties compared to traditionally used ferritic or austenitic steels. The main area of application are the chemical industry, construction of warehouses, tanks of vessels transporting products with high chemical activity (acid phosphoric, concentrated sulfuric acid, highly alkaline media) or equipment used: in the energy 
production, pulp, paper, food and petrochemical industries [9-17]. Figure 2 show the key advantages of duplex steels and cast steels.

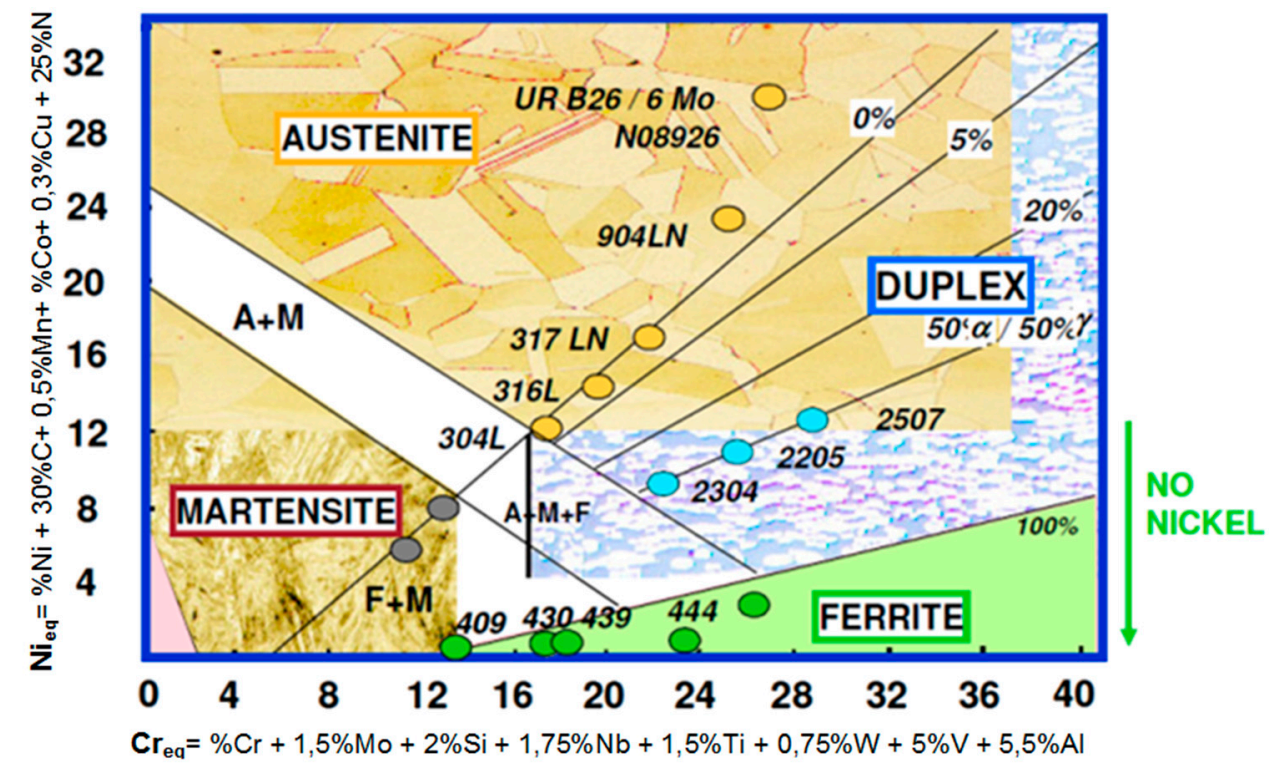

Figure 1. Schaeffler's graph-Based on $[4,5,7-9,14,16]$.

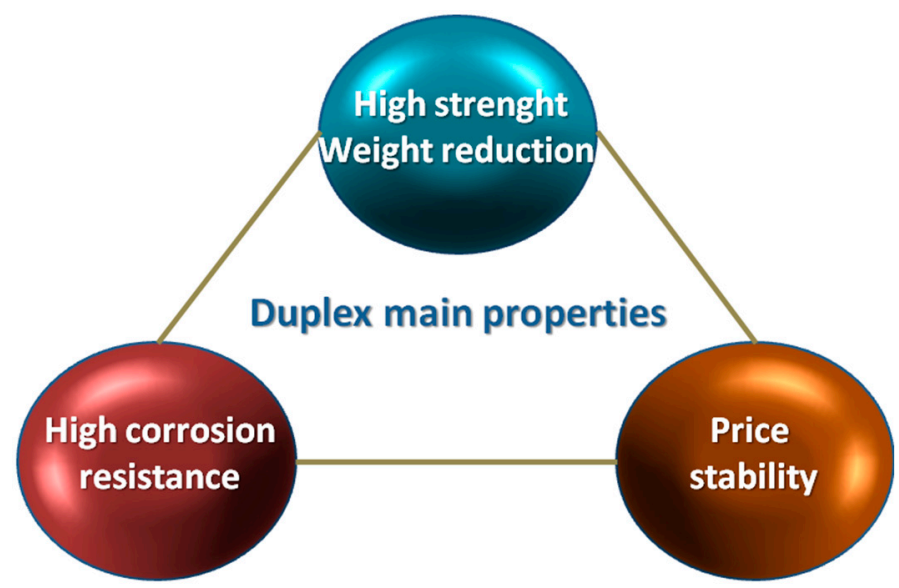

Figure 2. Schematic presentation of the most important advantages of duplex steels and cast steels.

Based on [15].

\section{Material and Research Methodology}

The subjects of the study were two grades of duplex steels X2CrNiMoN25-7-4 and X2CrNiMoCuN25-6-3, which chemical compositions are presented in Table 1. The microstructure of these materials were shown in earlier works $[1-3,10]$. They are characterized by low tendency to crystalize in form of column grains, which appearance is associated with an increase of carbon content-above $0.04 \% \mathrm{C}$ for copper-free steel X2CrNiMoN25-7-4 and 0.035\% C for X2CrNiMoCuN25-6-3. The chemical composition of materials was selected in such way that the content of key elements was very similar. The main difference was the addition of about $2.5 \%$ of copper, which not only allows the aging process [14,22-24], but also affects the liquidity and plasticity of duplex steel and cast steel [1-3,8-17,25-27]. 
Table 1. Chemical composition of tested steels according to standard PN-EN 10283: 2019, value in weight $\%$.

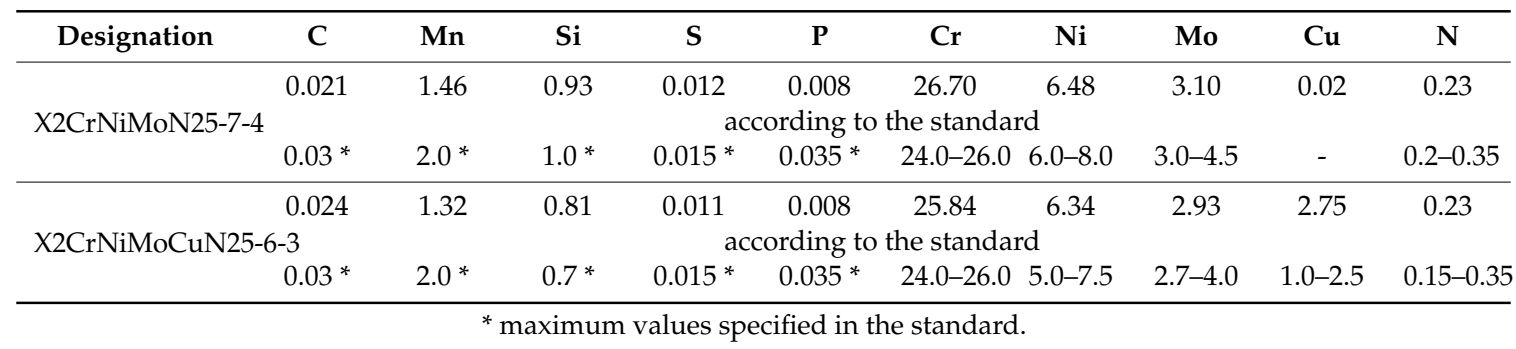

The conducted experimental researches were divided into the following stages:

- $\quad$ Making of Y-shaped castings with a wall thickness of $25.0 \mathrm{~mm}$ (Figure 3);

- Analysis of the microstructure of the materials in the raw state;

- Solution-annealing to remove the primary precipitated sigma phase;

- Hot deformation using the Gleeble 3800 Physical Simulation System with the Hydrawedge module;

- Analysis of materials microstructure after the plastic deformation process.
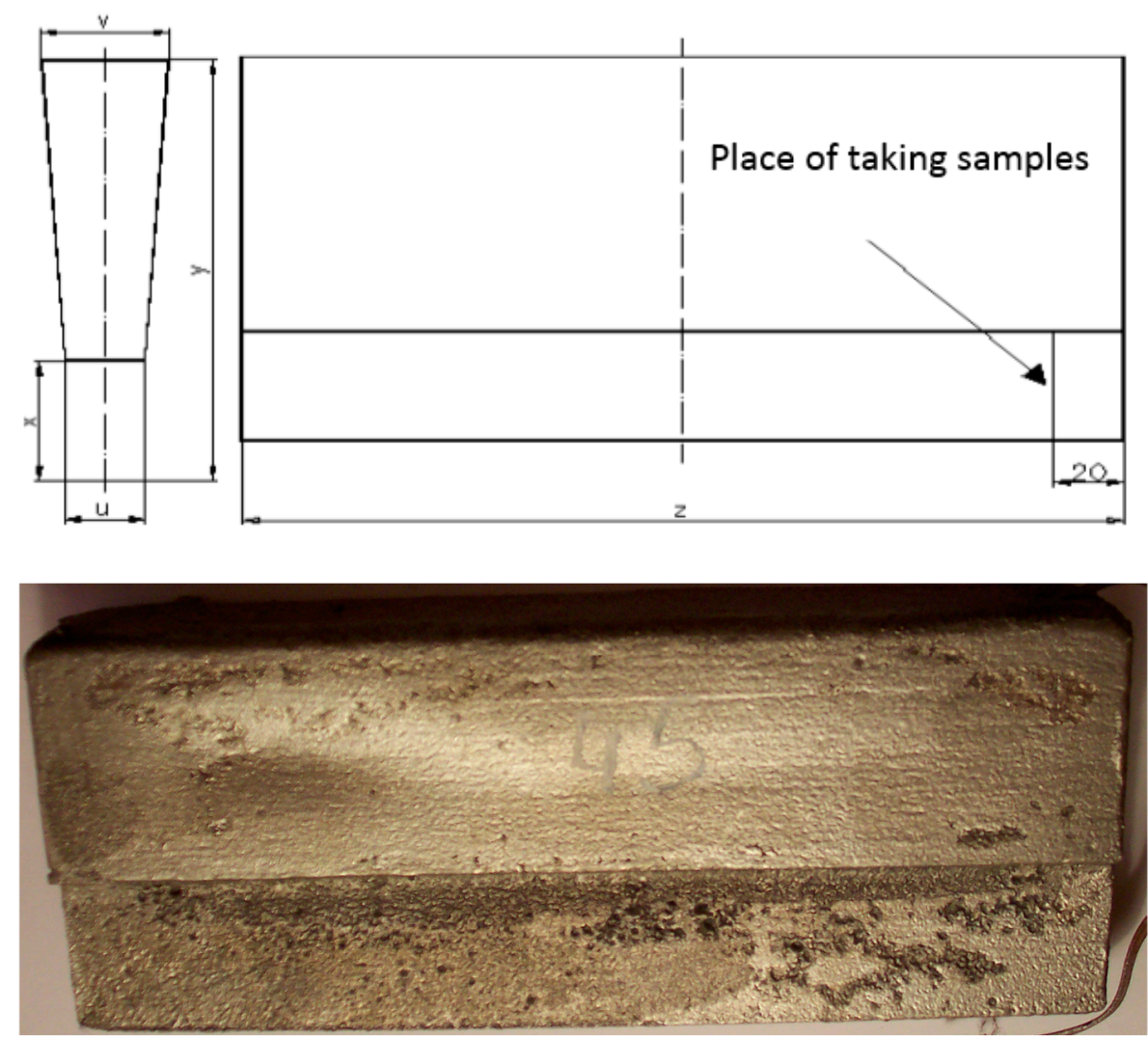

Figure 3. The shape of the cast with head.

\section{Obtained Results}

The microstructure of analyzed materials was revealed with the metallographic reagent Mi21Fe ( $30 \mathrm{~g}$ potassium ferricyanide, $30 \mathrm{~g}$ potassium hydroxide $60 \mathrm{~g}$ distilled water). The main advantage of this reagent was marking on different colors phases, what allows and helps easily analysis of microstructure. Figure 4 shows an example of microstructure-tested material in a raw state. As it can be seen the sigma phase have a specific brown color, austenite white or gray and ferrite light brown or yellow. This type of reagent also give the possibility to reveal other phase like the $\gamma^{\prime}$ known also as $\gamma_{2}$. 
a)
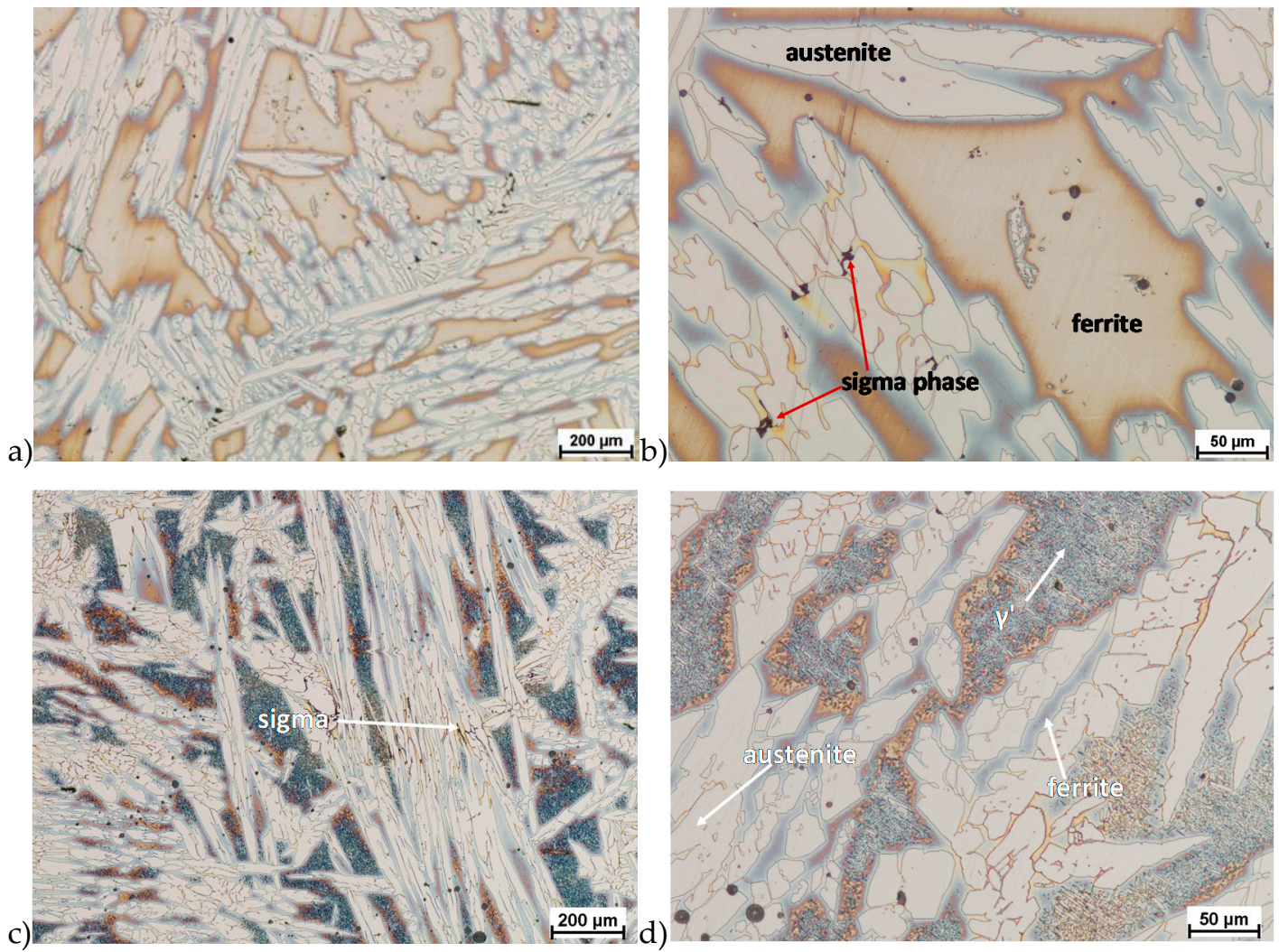

Figure 4. Exemplary microstructure in the raw state $(\mathbf{a}, \mathbf{b})$ the $\mathrm{X} 2 \mathrm{CrNiMoN} 25-7-4$ steel, $(\mathbf{c}, \mathbf{d})$ the X2CrNiMoCuN25-6-3 steel.

The structure of materials were analyzed with use of the light microscope and the phase content was determined using the Nis-Elements D application. The evaluation of the raw state microstructure showed that the material was characterized by presence of ferritic-austenitic grains with a small presence of $2 \%-2.5 \%$ of the $\sigma$ phase. According to literature study $[5,14,18,19,28-30]$ and the authors' research $[2,10,17,31]$, this phase volume was not harmful.

In the first stage of studies were made deformation of the raw state. In some cases of hot deformed samples, the cracks were observed. This was a basis for the microstructure analysis and some selected results are shown in Figure 5.

Evaluation of the microstructure showed that below $1100{ }^{\circ} \mathrm{C}$, can appear the initiation of phase $\sigma$ precipitation, what was observed for a deformation rate of $10.0 \mathrm{~s}^{-1}$. Quantitative analysis allowed to determine its share at the level of $10 \%-15 \%$ depending on the deformation temperature. The volume fraction of the phase increases with temperature decrease. Based on the obtained data, it was found that, the limit temperature below which the alloy should not be deformed was $1100{ }^{\circ} \mathrm{C}$ and it was definitely safer to apply lower deformation rates.

Hot deformation tests were also carried out for the $\mathrm{X} 2 \mathrm{CrNiMoCuN25-6-3}$ alloy, which was presented earlier works $[1,3,14]$. Cracks were also observed for this alloy using the same parameters as for the $\mathrm{X} 2 \mathrm{CrNiMoN25-7-4}$ alloy, but no new $\sigma$ phase precipitates were observed. The initial share of this phase was at a similar level of about $2 \%-2.5 \%$. Therefore, it was proposed to carry out the solution-annealed process to eliminate it completely. The material prepared for deformation was solution-annealed at $1150^{\circ} \mathrm{C}$ for $120 \mathrm{~min}$. Figures 6 and 7 show examples of tested-steel microstructures after solution-annealed process.

As it can be seen the material without cooper was characterized by presence of the austenite and ferrite. In the duplex steel with addition of cooper was also present the $\gamma^{\prime}$ also named $\gamma_{2}$ phase $[16,23,25,29,30,32]$. 
In the further part of the work, deformation tests were carried out for both tested alloys according to the parameters presented in Tables 2 and 3. Temperatures 850 and $1100{ }^{\circ} \mathrm{C}$ were selected on the basis of earlier tests, as well as the range of strain rate and the values of the true deformation.

a)
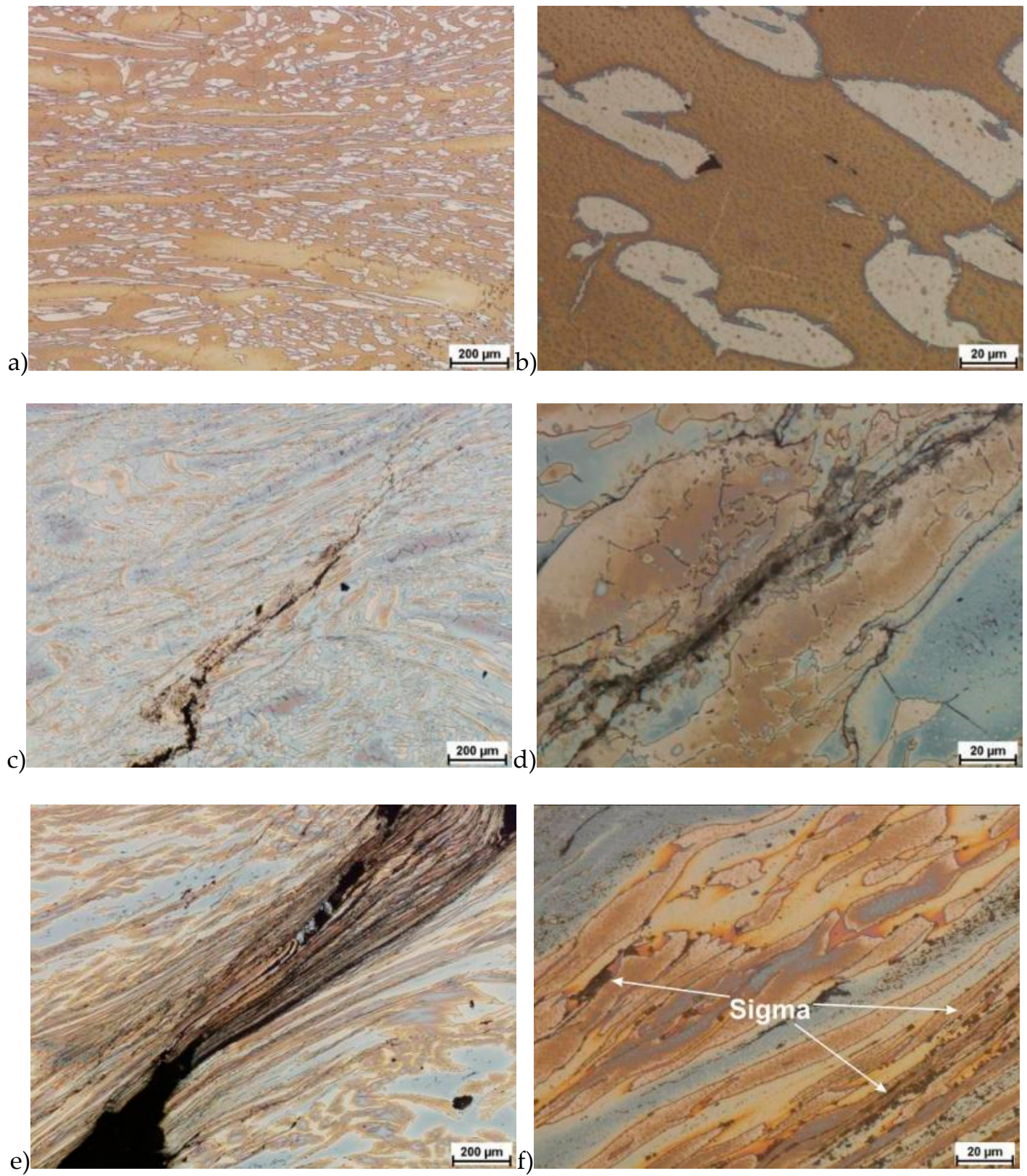

Figure 5. Exemplary microstructures of the $\mathrm{X} 2 \mathrm{CrNiMoN25-7-4}$ steel: a) deformation at temperature $1150{ }^{\circ} \mathrm{C}$ with strain rate $1.0 \mathrm{~s}^{-1}, \mathbf{b}$ ) deformation at temperature $1150{ }^{\circ} \mathrm{C}$ with strain rate $1.0 \mathrm{~s}^{-1}, \mathbf{c}$ ) deformation at temperature $1100{ }^{\circ} \mathrm{C}$ with strain rate $10.0 \mathrm{~s}^{-1}, \mathrm{~d}$ ) deformation at temperature $1100{ }^{\circ} \mathrm{C}$ with strain rate $10.0 \mathrm{~s}^{-1}$, e) deformation at temperature $900^{\circ} \mathrm{C}$ with strain rate $10.0 \mathrm{~s}^{-1}, \mathbf{f}$ ) deformation at temperature $900{ }^{\circ} \mathrm{C}$ with strain rate $10.0 \mathrm{~s}^{-1}$. 
a)

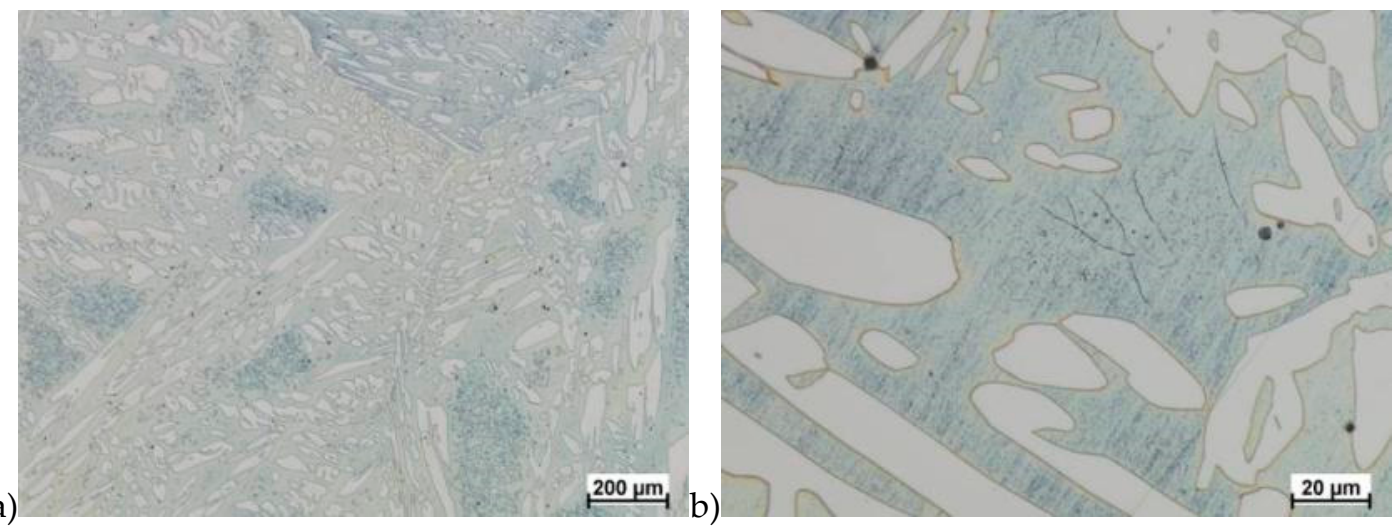

Figure 6. Microstructure of the $\mathrm{X} 2 \mathrm{CrNiMoN25-7-4} \mathrm{steel} \mathrm{before} \mathrm{deformation.} \mathrm{a)} \mathrm{magn.} \mathrm{50 \times ,} \mathrm{b)} \mathrm{500×.}$

a)
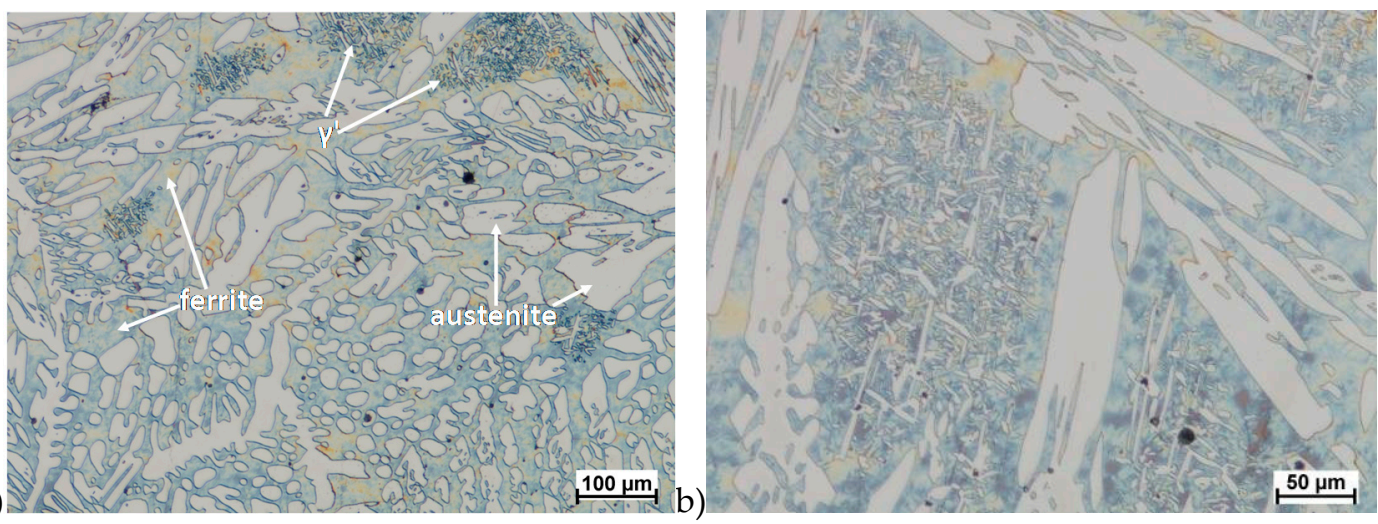

Figure 7. Microstructure of the $\mathrm{X} 2 \mathrm{CrNiMoCuN25-6-3}$ steel before deformation. a) magn. 100×, b) 200×.

Table 2. Temperature and deformation parameters used during tests for X2CrNiMoN25-7-4 steel.

\begin{tabular}{ccccc}
\hline Design & Temperature, $^{\circ} \mathbf{C}$ & Strain Rate, $\mathbf{s}^{\mathbf{- 1}}$ & True Deformation & Pause Time, $\mathbf{s}$ \\
\hline 1 & 850 & 1.0 & $\varepsilon 1=0.2$ & - \\
2 & 850 & 10.0 & $\varepsilon 1=0.2$ & - \\
3 & 1100 & 1.0 & $\varepsilon 1=0.2$ & - \\
4 & 1100 & 10.0 & $\varepsilon 1=0.2$ & - \\
5 & 850 & 1.0 & $\varepsilon 1=\varepsilon 2=\varepsilon 3=0.2$ & 0.25 \\
6 & 1100 & 1.0 & $\varepsilon 1=\varepsilon 2=\varepsilon 3=0.2$ & -25 \\
7 & 850 & 1.0 & $\varepsilon 1=0.3$ & - \\
8 & 850 & 10.0 & $\varepsilon 1=0.3$ & - \\
9 & 1100 & 1.0 & $\varepsilon 1=0.3$ & - \\
10 & 1100 & 10.0 & $\varepsilon 1=0.3$ & 0.25 \\
11 & 850 & 1.0 & $\varepsilon 1=\varepsilon 2=\varepsilon 3=0.2$ & - \\
12 & 850 & 10.0 & $\varepsilon 1=0.45$ & - \\
13 & 850 & 10.0 & $\varepsilon 1=0.5$ & - \\
14 & 850 & 10.0 & $\varepsilon 1=0.6$ & - \\
15 & 850 & 10.0 & $\varepsilon 1=\varepsilon 2=\varepsilon 3=\varepsilon 4=0.3$ & 0.25 \\
16 & 850 & 10.0 & & \\
\hline
\end{tabular}


Table 3. Temperature and deformation parameters used during tests for X2CrNiMoCuN25-6-3 steel.

\begin{tabular}{ccccc}
\hline Design. & Temperature, $^{\circ} \mathbf{C}$ & Strain Rate, $\mathbf{s}^{\mathbf{1}}$ & True Deformation & Pause Time, $\mathbf{s}$ \\
\hline $1 \mathrm{a}$ & 850 & 1.0 & $\varepsilon 1=0.2$ & - \\
2a & 850 & 10.0 & $\varepsilon 1=0.2$ & - \\
3a & 1100 & 10.0 & $\varepsilon 1=0.2$ & - \\
$4 \mathrm{a}$ & 1100 & 1.0 & $\varepsilon 1=0.2$ & - \\
$5 \mathrm{a}$ & 850 & 1.0 & $\varepsilon 1=\varepsilon 2=\varepsilon 3=0.2$ & 0.25 \\
6a & 1100 & 1.0 & $\varepsilon 1=\varepsilon 2=\varepsilon 3=0.2$ & 0.25 \\
$7 \mathrm{a}$ & 850 & 10.0 & $\varepsilon 1=0.3$ & - \\
$8 \mathrm{a}$ & 850 & 1.0 & $\varepsilon 1=0.3$ & - \\
$9 \mathrm{a}$ & 1100 & 10.0 & $\varepsilon 1=0.3$ & - \\
$10 \mathrm{a}$ & 1100 & 1.0 & $\varepsilon 1=0.3$ & 0.25 \\
$11 \mathrm{a}$ & 850 & 10.0 & $\varepsilon 1=0.4$ & - \\
$12 \mathrm{a}$ & 850 & 10.0 & $\varepsilon 1=\varepsilon 2=\varepsilon 3=0.3$ & - \\
$13 \mathrm{a}$ & 850 & 10.0 & $\varepsilon 1=\varepsilon 2=\varepsilon 3=\varepsilon 4=0.3$ & 0.25 \\
$14 \mathrm{a}$ & 850 & 10.0 & & 0.25 \\
$15 \mathrm{a}$ & 850 & &
\end{tabular}

The obtained results (no crack observed) showed that the $\mathrm{X} 2 \mathrm{CrNiMoN25-7-4}$ steel was characterized by good plasticity in the tested temperature range for true deformation 0.2 and 0.3 for both deformation rates 1.0 and $10 \mathrm{~s}^{-1}$. Figures $8-15$ show examples of microstructures deformed according to different variants according to Table 2 .
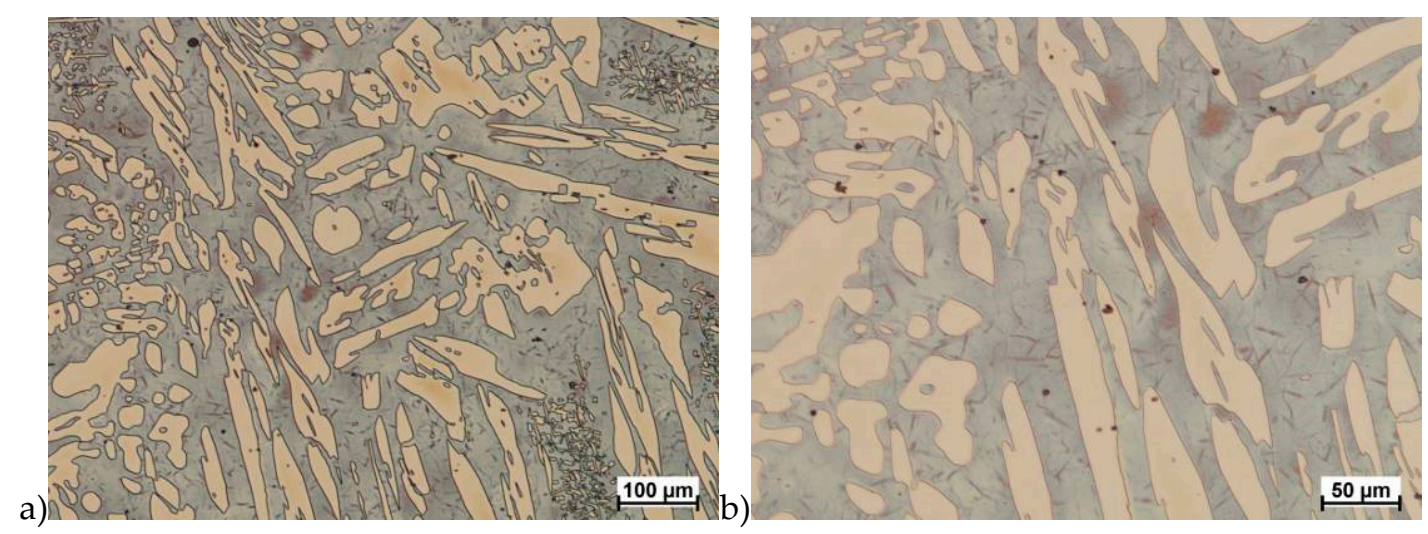

Figure 8. Microstructure of the $\mathrm{X} 2 \mathrm{CrNiMoN25-7-4}$ steel deformed according to the variant 1. a) magn. $100 \times$, b) $200 \times$.
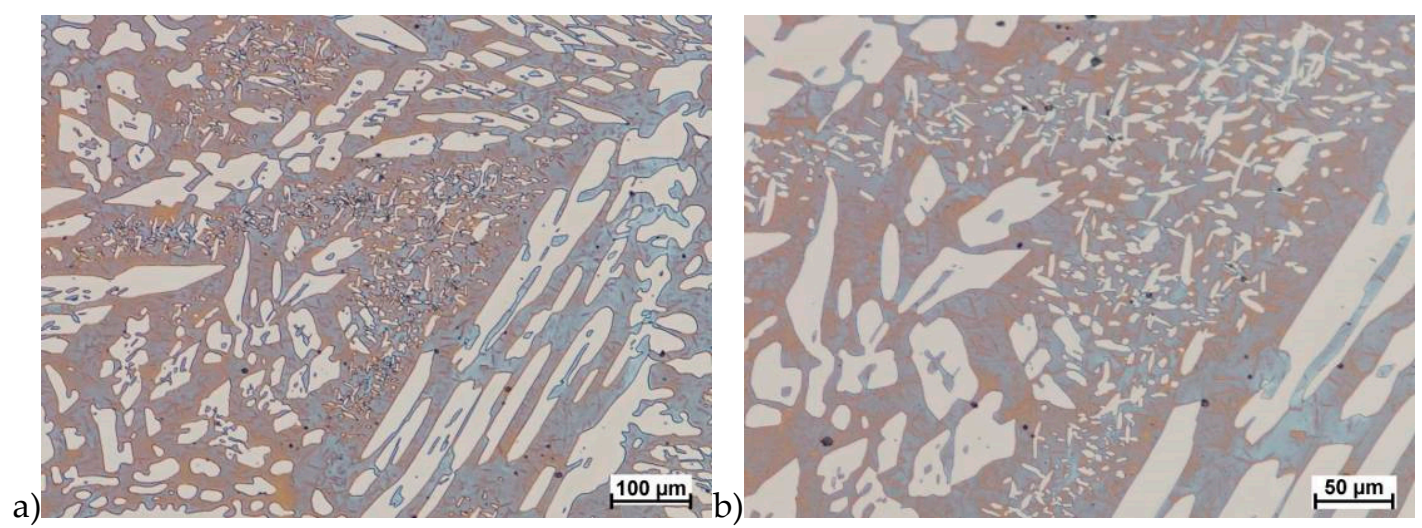

Figure 9. Microstructure of the $\mathrm{X} 2 \mathrm{CrNiMoN} 25-7-4$ steel deformed according to the variant 2. a) magn. $100 \times$, b) $200 \times$. 
a)
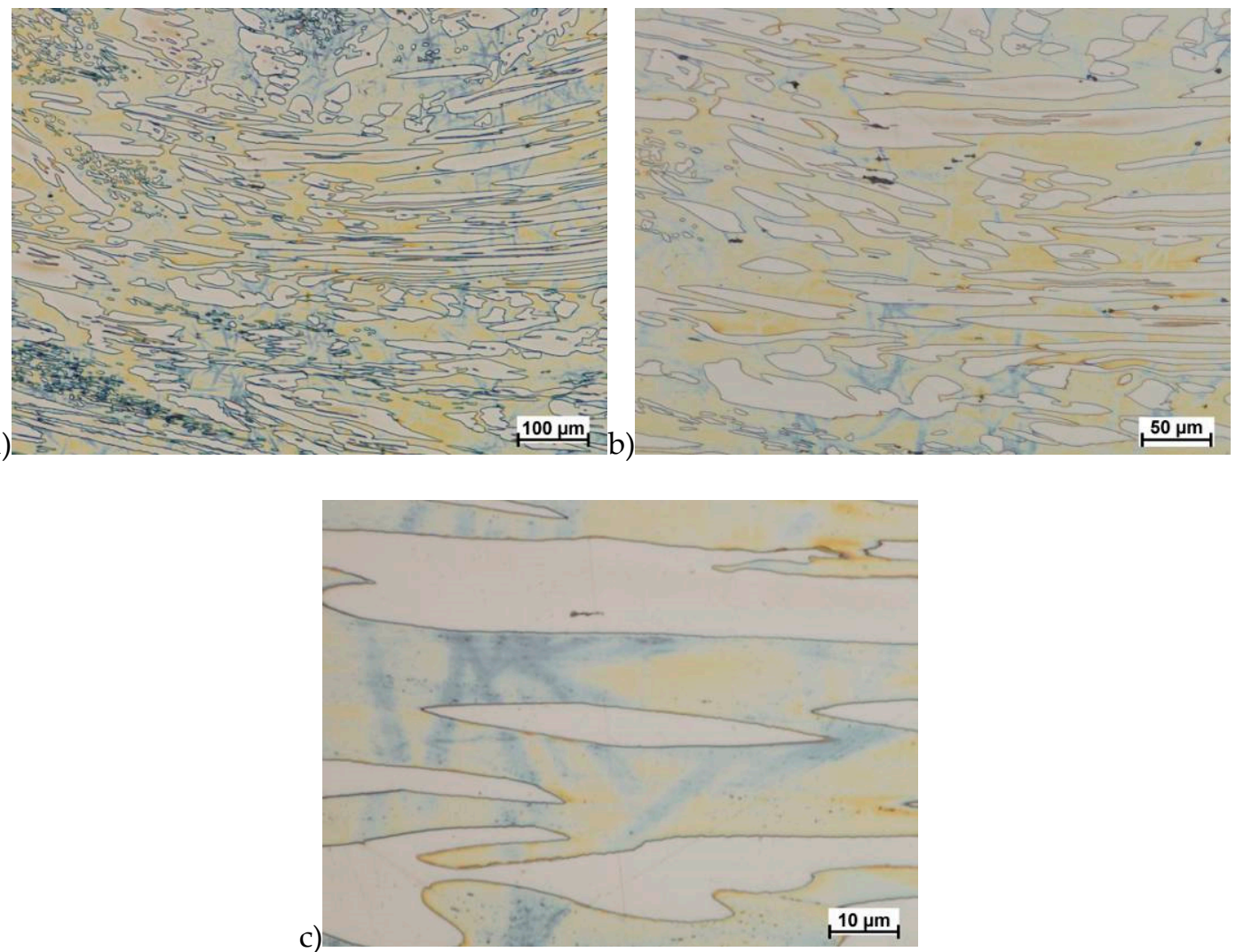

Figure 10. Microstructure of the $\mathrm{X} 2 \mathrm{CrNiMoN} 25-7-4$ steel deformed according to the variant 5 . a) magn. $100 \times$, b) $200 \times$, c) $1000 \times$.
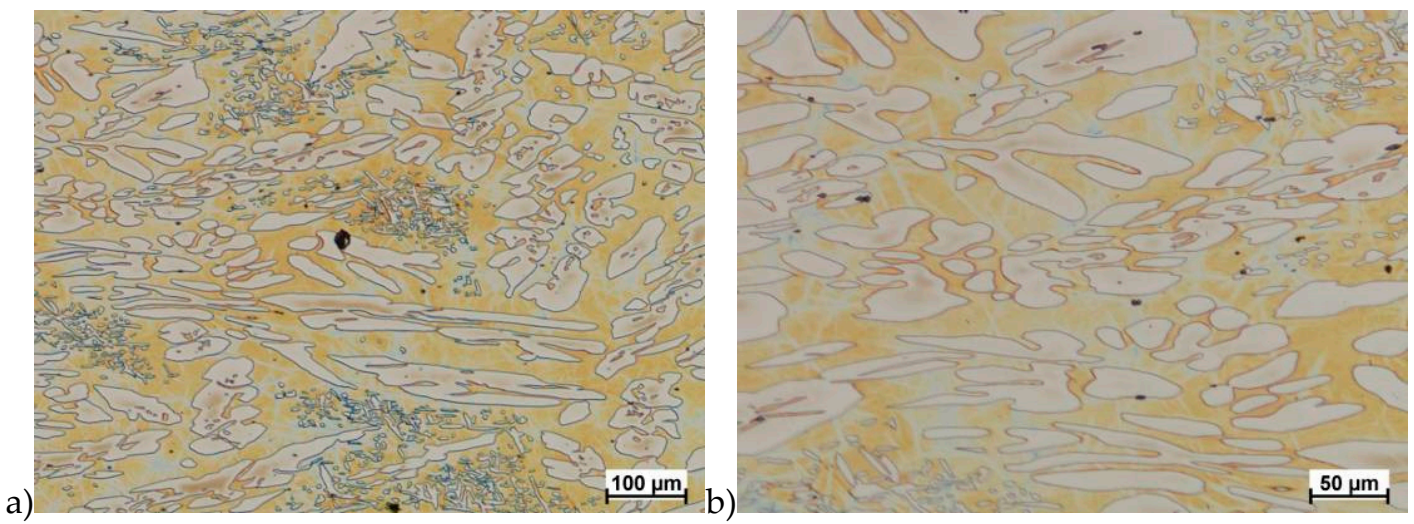

Figure 11. Microstructure of the $\mathrm{X} 2 \mathrm{CrNiMoN} 25-7-4$ steel deformed according to the variant 8 . a) magn. $100 \times$, b) $200 \times$.

The deformation according to variant 16 led to the crack of the sample. It should be emphasized, that however in this case a total relative deformation of 1.2 was achieved in a relatively short time and with a strain rate of $10 \mathrm{~s}^{-1}$.

The true deformation in one pass by 0.6 at a strain rate of $10 \mathrm{~s}^{-1}$ at $850{ }^{\circ} \mathrm{C}$ (Figure 13) causes the precipitation of the $\sigma$ phase. They are in the form of single colonies separated from each other by the ferrite-austenite border as well as small in the ferrite, near the borders with austenite. Quantitative analysis showed the presence of about $3 \%-5 \%$ of the newly separated $\sigma$ phase. Figure 13 show the microstructure of the sample after deformation according to variant 15. 
a)
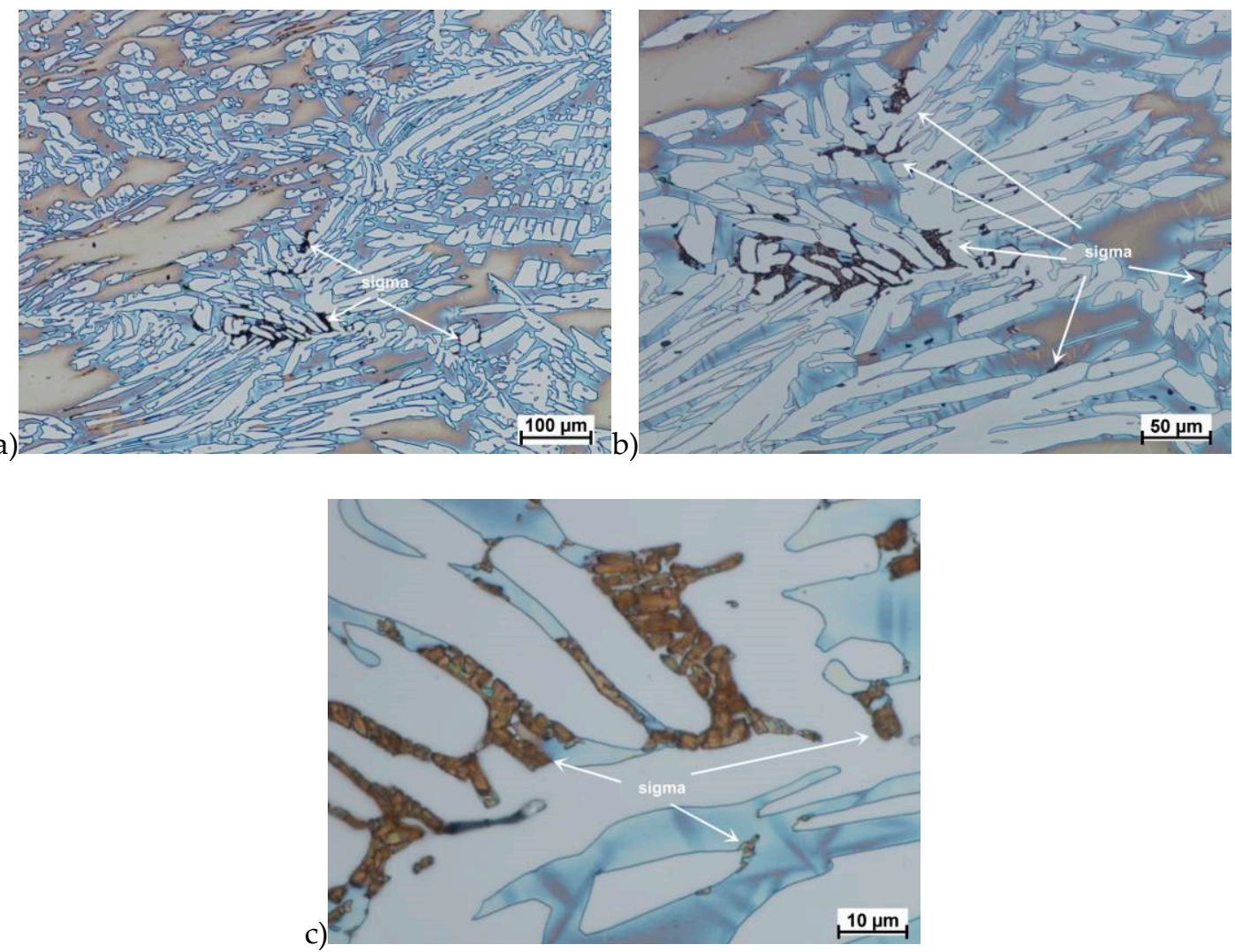

Figure 12. Microstructure of the $\mathrm{X} 2 \mathrm{CrNiMoN} 25-7-4$ steel deformed according to the variant 15 . a) magn. $100 \times$, b) $200 \times$, c) $1000 \times$.
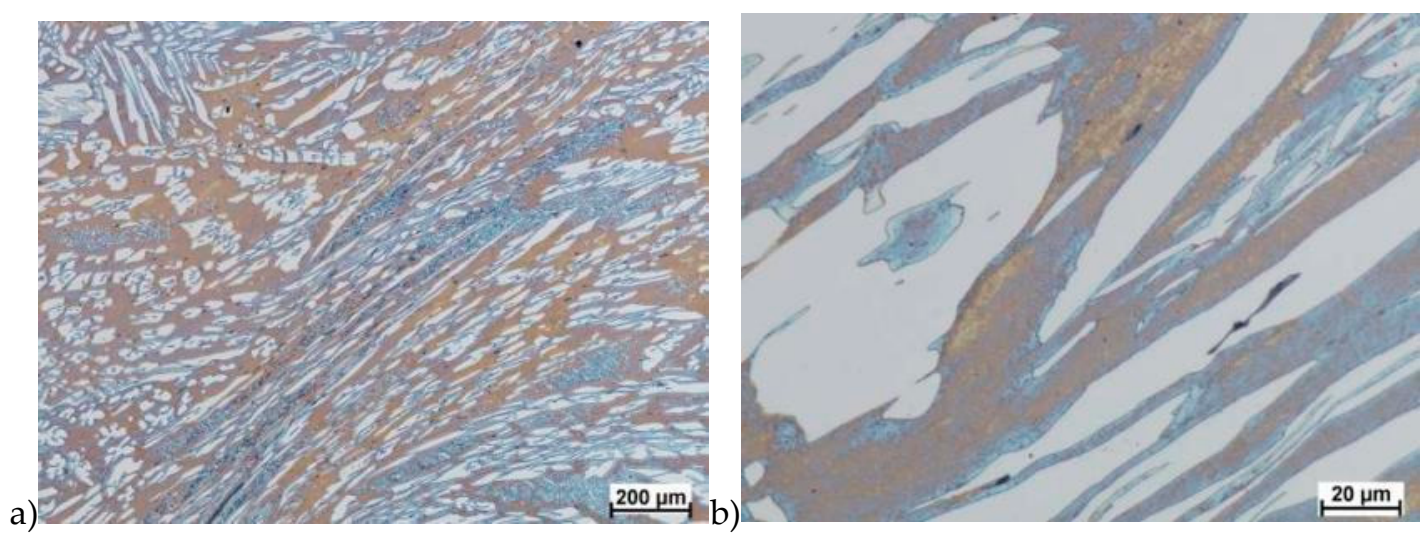

Figure 13. Microstructure of the $\mathrm{X} 2 \mathrm{CrNiMoN25-7-4}$ steel deformed according to the variant 13. a) magn. $50 \times$, b) $500 \times$.

Microstructure after deformation according to variants 13 and 14 are presented in Figures 14 and 15. As a result of the tests, the material subjected to 0.45 true deformation do not crack, while the sample subjected to 0.5 true deformation cracked. It should be noted that, the application of 0.5 true deformation led to the appearance of very small $\sigma$ phase precipitation. They are located in the area of the largest strains on the ferrite-austenite boundaries (Figure 14). The number of precipitates was negligible and limited only to the zone with the largest deformation. 

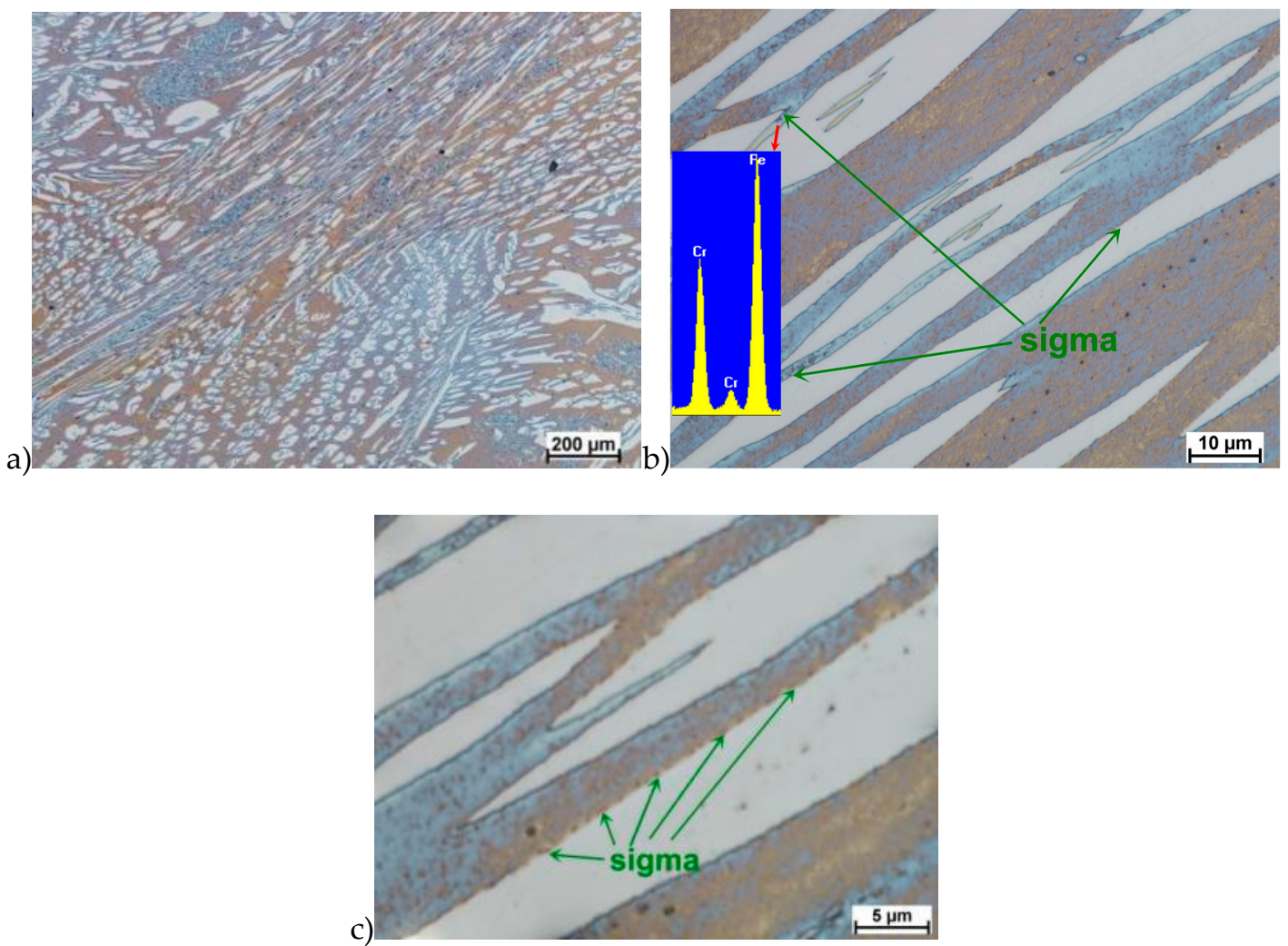

Figure 14. Microstructure of the $\mathrm{X} 2 \mathrm{CrNiMoN} 25-7-4$ steel deformed according to the variant 14 . a) magn. $50 \times$, b) $1000 \times$, c) $2250 \times$.
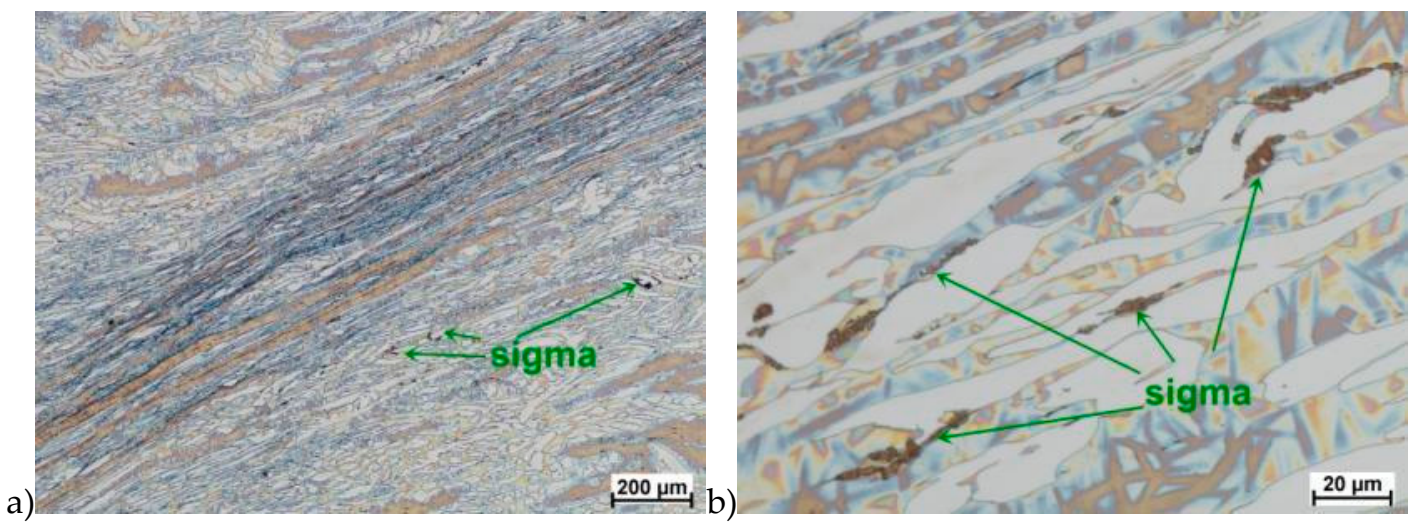

Figure 15. Microstructure of the $\mathrm{X} 2 \mathrm{CrNiMoN25-7-4}$ steel deformed according to the variant 16 . a) magn. $50 \times$, b) $500 \times$.

The use of four passes with true deformation 0.3 , strain rate of $10.0 \mathrm{~s}^{-1}$ at the temperature of $850^{\circ} \mathrm{C}$ also caused the precipitation of the $\sigma$ phase, which are shown in Figure 16. Despite the fact that the deformation 0.3 was defined as safe, the deformation rate and short break time of $0.25 \mathrm{~s}$ probably do not allow for full stress relaxation. In this variant, the location and percentage of new precipitates was similar to that observed in variant 15 , with the difference, that more precipitates were visible as elongated colonies at the ferrite-austenite borders.

Based on the tests, was possible to develop the relationship of the percentage share of phase $\sigma$ as a function of time and strain in the form of an equation and the surface shown in Figure 16.

$$
\sigma_{\text {def }}=-0.004 \varepsilon^{2}-5128.426 t_{\varepsilon}^{2}-0.314 \varepsilon+156.068 t_{\varepsilon}+12.287 \varepsilon \cdot t_{\varepsilon}+0.017
$$


where:

$\sigma_{\text {def }}-\sigma$ phase percentage,

$\varepsilon$-strain, \%,

$\mathrm{t}_{\varepsilon}$-deformation time, $\mathrm{s}$.

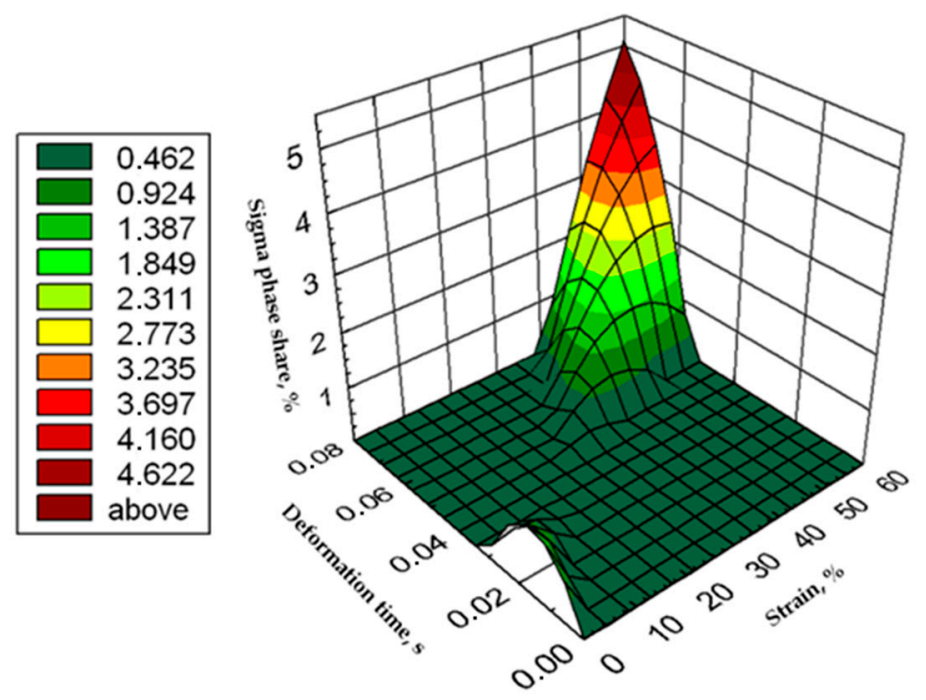

Figure 16. Graphic presentation of the relationship of the percentage share of $\sigma$ phase as a function of time and strain for $\mathrm{X} 2 \mathrm{CrNiMoN} 25-7-4$ steel at $850{ }^{\circ} \mathrm{C}$.

The X2CrNiMoCuN25-6-3 steel, similarly to the grade without copper, was subjected to solution-annealed process in order to completely eliminate $\sigma$ phase precipitations. The tests were carried out according to the parameters shown in Table 3. Figures 17-22 show the microstructure of the material subjected to deformation according to variants: 1a, 2a, 5a, 13a, 14a and 15a. The deformed sample according to variants $14 \mathrm{a}$ and $15 \mathrm{a}$ cracks, similarly to sample variant 14 , what indicates that the material exceeded the maximum stress values. In the case of these variants it should be emphasized that the test of repeated deformation was dynamic, fast and the time of single deformation was about $0.05 \mathrm{~s}$.

a)
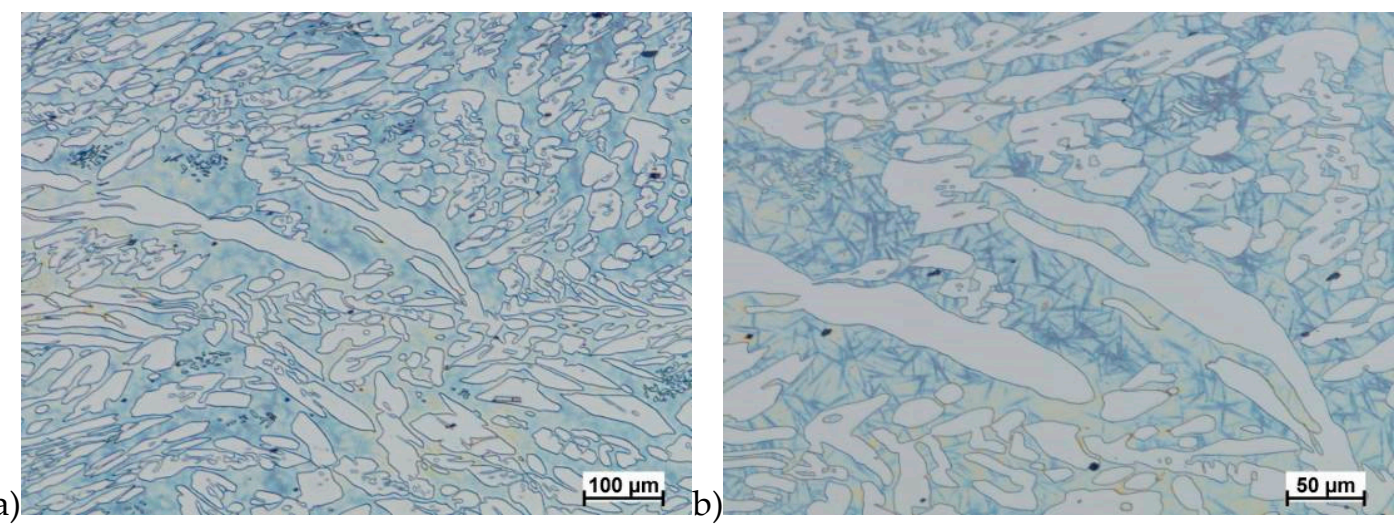

Figure 17. Microstructure of the $\mathrm{X} 2 \mathrm{CrNiMoCuN25-6-3}$ steel deformed according to the variant $1 \mathrm{a}$. a) magn. $100 \times$, b) $200 \times$. 

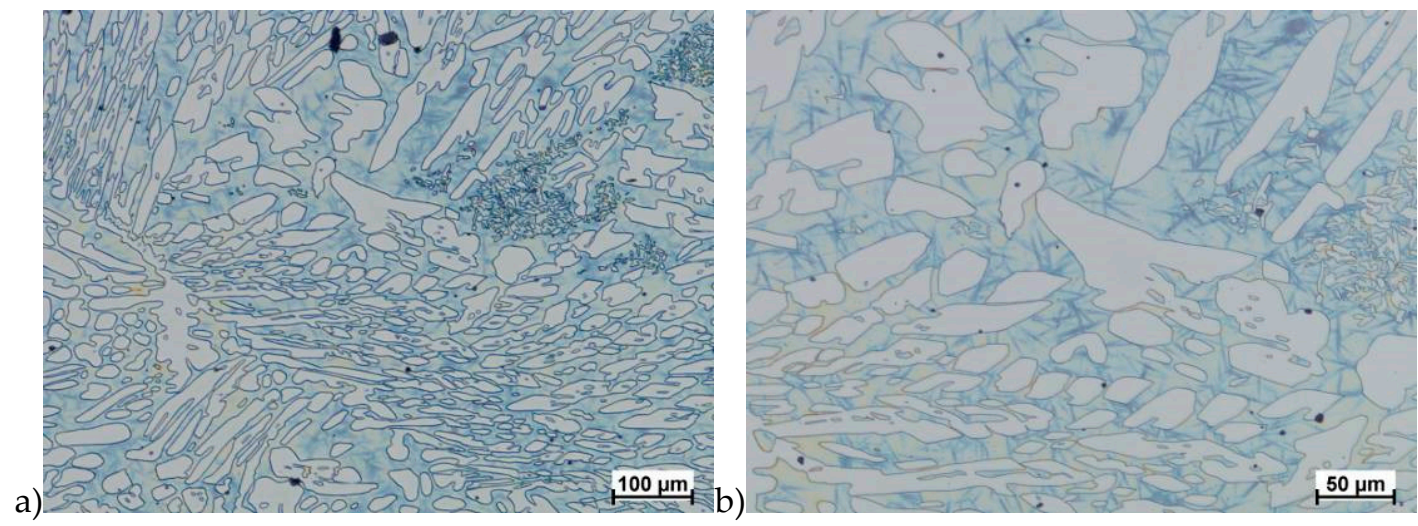

Figure 18. Microstructure of the $\mathrm{X} 2 \mathrm{CrNiMoCuN25-6-3}$ steel deformed according to the variant $2 \mathrm{a}$. a) magn. $100 \times$, b) $200 \times$.
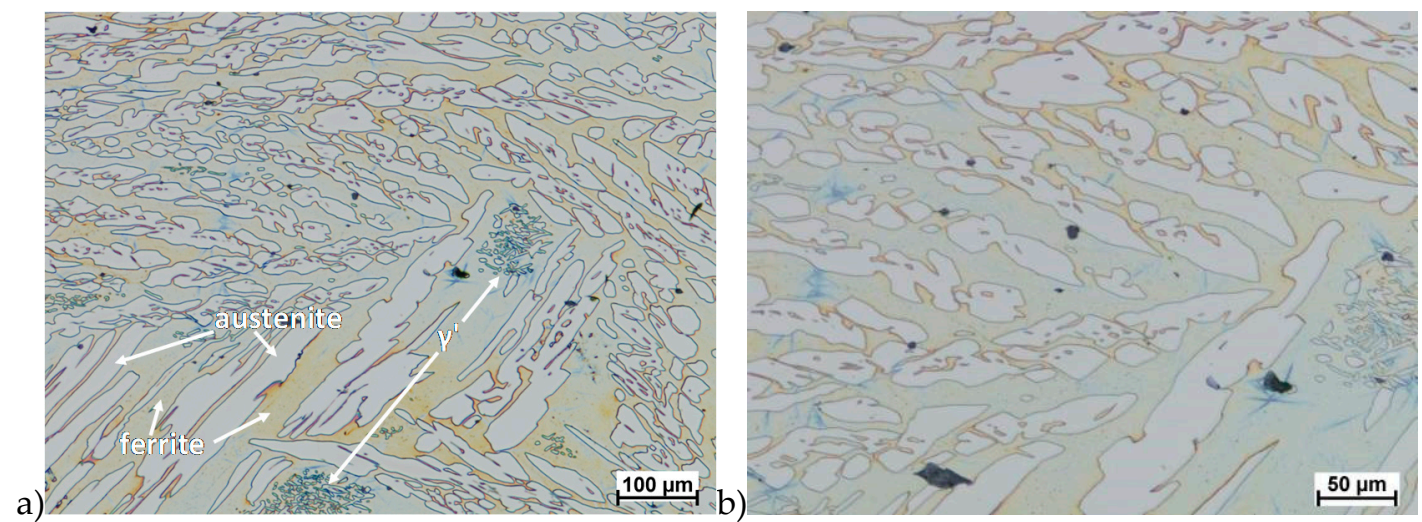

Figure 19. Microstructure of the $\mathrm{X} 2 \mathrm{CrNiMoCuN25-6-3}$ steel deformed according to the variant $5 \mathrm{a}$. a) magn. $100 \times$, b) $200 \times$.
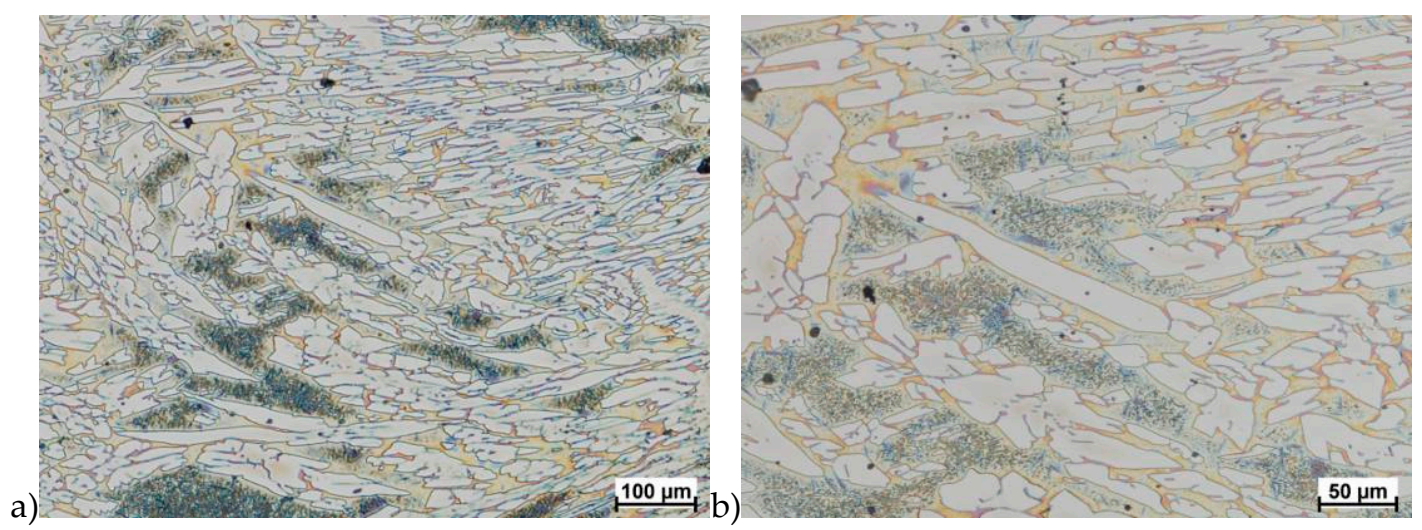

Figure 20. Microstructure of the $\mathrm{X} 2 \mathrm{CrNiMoCuN25-6-3}$ deformed according to the variant 13a. a) magn. $100 \times$, b) $200 \times$.

Similar to $\mathrm{X} 2 \mathrm{CrNiMoN25-7-4} \mathrm{steel,} \mathrm{it} \mathrm{has} \mathrm{equiaxed} \mathrm{ferrite} \mathrm{and} \mathrm{austenite} \mathrm{grains} \mathrm{in} \mathrm{its} \mathrm{raw} \mathrm{state.}$ The analysis of microstructure of the $\mathrm{X} 2 \mathrm{CrNiMoCuN25-6-3} \mathrm{steel} \mathrm{did} \mathrm{not} \mathrm{show} \mathrm{any} \mathrm{presence} \mathrm{of} \mathrm{the}$ $\sigma$ phase. Although as it was mentioned in some cases were observed cracks, but in the area around them-and in the deformation zone-no precipitation of this phase were observed. In the materials was also noticed no presence of the $\varepsilon$ phase, which according to $[23,24,32,33]$ should be observed. As it was known this phase reduce hot ductility and gave the possibility for precipitation hardening. 
However, some authors [34] who investigated duplex steels with copper content about $2.5 \%$ have not found it, but others [35] noticed its presence in materials with about $3 \%$ of $\mathrm{Cu}$.

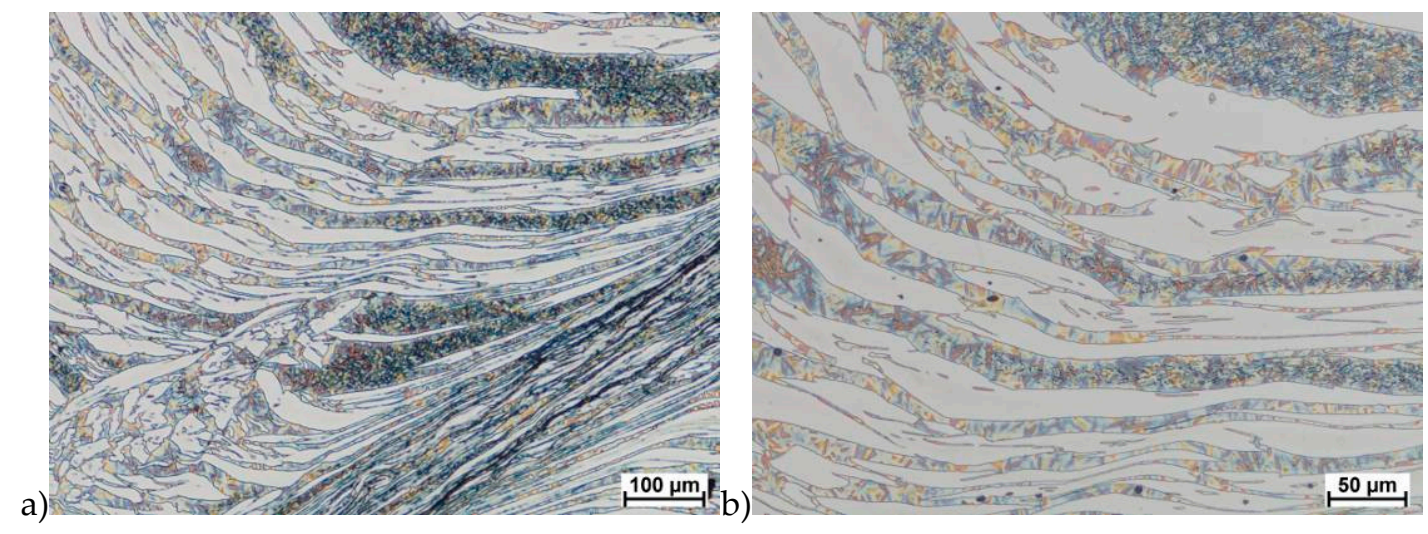

Figure 21. Microstructure of the $\mathrm{X} 2 \mathrm{CrNiMoCuN25-6-3}$ deformed according to the variant 14a. a) magn. $100 \times$, b) $200 \times$.

a)
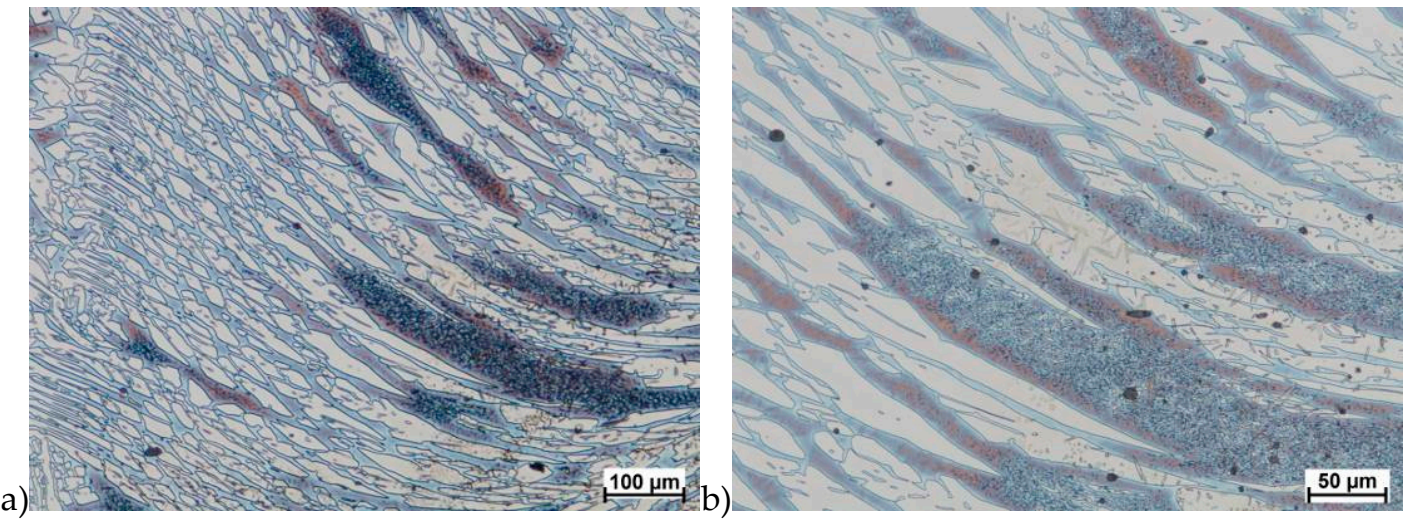

Figure 22. Microstructure of the $\mathrm{X} 2 \mathrm{CrNiMoCuN25-6-3}$ deformed according to the variant 15a. a) magn. $100 \times$, b) $200 \times$.

The obtained results clearly shows that the $2.5 \%$ copper addition, in the studied temperature-deformation range, eliminates the tendency to precipice the $\sigma$ phase as a result of hot plastic deformation.

\section{Summary}

The plasticity analysis of X2CrNiMoN25-7-4 steel showed that the delivery state was an important parameter affecting hot plastic deformability. The material deformed in preliminary tests, not subjected to solution-annealed, was characterized by about $2 \%-2.5 \%$ of the $\sigma$ phase share and lower plasticity. The tests carried out in the temperature range $800-1150{ }^{\circ} \mathrm{C}$ showed a tendency to form cracks. I was found that for this deformation rate below $1100^{\circ} \mathrm{C}$, the initiation of phase $\sigma$ separation may occur, which is shown in Figure 6e,f. Quantitative analysis showed that, depending on the temperature, its share can be $10 \%-15 \%$. This was a significant increase of $4-6$ times. In all areas of cracks of deformed samples in the temperature range of $800-1050{ }^{\circ} \mathrm{C}$ for strain rate $10.0 \mathrm{~s}^{-1}$ were visible precipitations, which means that it can both initiate and facilitate destruction. It should also be noted that in microstructure of samples deformed at $1100{ }^{\circ} \mathrm{C}$, no $\sigma$ phase was observed in the areas of cracks.

The materials subjected to solution-annealed at $1150^{\circ} \mathrm{C}$ for $120 \mathrm{~min}$ had significantly better plastic properties. The obtained results showed that the tested steels were characterized by good plasticity in the tested temperature range for true deformations 0.2 and 0.3 for both strain rates 1.0 and $10 \mathrm{~s}^{-1}$. 
It should be noted that 0.5 deformation according to variant 14 caused the appearance of $\sigma$ phase precipitates, however, its share was negligible, and the precipitations were very small. This is the proof that this is the initial stage, which should be considered as the moment of the beginning of its separation in the studied temperature and deformation conditions. The deformation in one pass by 0.6 at a speed of $10 \mathrm{~s}^{-1}$ at a temperature of $850^{\circ} \mathrm{C}$ (Figure 13) causes the separation of the $\sigma$ phase in the form of single, separated colonies at the ferrite-austenite borders as well as small precipitates in the ferrite, near the borders with austenite. This area was a place of privileged sigma phase release, which was associated with the phenomena of $\mathrm{Cr}$ and $\mathrm{Ni}$ microsegregation for ferrite and austenite. The use of four passes with strain 0.3 and the strain rate of $10 \mathrm{~s}^{-1}$ at temperature of $850{ }^{\circ} \mathrm{C}$ also caused the separation of the $\sigma$ phase. The observed amount was similar to variant 15 , with the difference that more precipitates have the character of longitudinal colonies at the ferrite-austenite boundaries. In this case, despite the fact that the actual strain 0.3 was defined as safe, the strain rate and short break time probably do not allow to full stress relaxation.

The plasticity of the $\mathrm{X} 2 \mathrm{CrNiMoCuN25-6-3}$ steel was similar to the $\mathrm{X} 2 \mathrm{CrNiMoN25-7-4}$ steel. Although both materials cracks during performed tests. In the microstructure of the grade with copper was not observed $\sigma$ phase. This steel was characterized by the presence of not only main phases like austenite and ferrite but also the $\gamma^{\prime}(\gamma 2)$. The only observed precipitations of sigma phase were observed during initial tests which concerned no solution-annealed material. In those tests the amount of precipitated $\sigma$ phase during crystallization was preserved and after deformation its amount was similar. After solution-annealing process in the microstructure of the steel with $2.5 \%$ of copper, deformed in the $850^{\circ} \mathrm{C}$, none $\sigma$ phase precipitation were observed. It should be mentioned that deformation in this range of temperature can provide the grain refining and changes in texture as it is presented in [19]. Lack of $\sigma$ phase precipitation give the possibility for deformation, for example rolling process in the range of $600-900^{\circ} \mathrm{C}$. This is the temperature of creation of $\sigma$ phase.

Author Contributions: Formal analysis, G.S., A.S. and D.R.; Investigation, G.S.; Resources, G.S.; Supervision, D.R.; Visualization, A.S.; Writing - original draft, G.S.; Writing - review \& editing, G.S. All authors have read and agreed to the published version of the manuscript.

Funding: This research received no external funding.

Conflicts of Interest: The authors declare no conflict of interest.

\section{References}

1. Stradomski, G. The assessment of the $\mathrm{X} 2 \mathrm{CrNiMo25-6-3} \mathrm{duplex} \mathrm{steel} \mathrm{plasticity.} \mathrm{METAL} \mathrm{2014.} \mathrm{In} \mathrm{Proceedings}$ of the 23rd International Conference on Metallurgy and Materials, Brno, Czech Republic, 21-23 May 2014; pp. $425-430$.

2. Stradomski, G. Wpływ struktury pierwotnej stali duplex $\mathrm{X} 2 \mathrm{CrNiMo} 25-6-3$ oraz $\mathrm{X} 2 \mathrm{CrNiMoCuN25-6-3-3}$ na jej plastyczność. Hutnik Wiadomości Hutnicze 2015, 82, 122-125.

3. Stradomski, G. Określenie zakresu plastyczności stali X2CrNiMo25-6-3. In Proceedings of the XV International Scientific Conference, New Technologies and Achievements in Metallurgy and Material Engineering, Czestochowa, Poland, 29-30 May 2014; pp. 156-160.

4. Charles, J. The duplex stainless steels: Materials to meet your needs. In Proceedings of the Duplex Stainless Steel Conference, Beaune, France, 28-30 October 1991; Volume 1, pp. 1-48.

5. Von Eckhart, H.; Dos Santos, R. Steuerung der Erstarrungsmorphologie austenitisch-ferritischer Superduplex-Stahle. Giesserei 2004, 91, 18-28.

6. A Non-Rusting Steel. Sheffield Invention Especially Good for Table Cutlery. New York Times, 31 January 1915.

7. Shankar, V.; Gill, T.P.S.; Mannan, S.L.; Sundaresan, S. Solidification cracking in austenitic stainless steel welds. Sadhana 2003, 28, 359-382. [CrossRef]

8. Blicharski, M. Inżynieria Materiałowa; WNT: Warszawa, Poland, 2004.

9. Charles, J. Duplex Stainless Steels-A Review after DSS ‘07 held in Grado. Steel Res. Int. 2008, 79, 455-465. [CrossRef] 
10. Stradomski, G. Effect of Sigma Phase Morphology on the Properties of Steel and Duplex Cast Steels, Series Monographs No. 61; The Publishing House of the Faculty of Production Engineering and Materials Technology of the Czestochowa University of Technology: Czestochowa, Poland, 2016.

11. Marken, L. Application of duplex and super duplex stainless steels in the offshore industry-Case histories. In Proceedings of the Stainless Steel World Conference \& Expo, Maastricht, Netherlands, 8-10 November 2005; pp. 318-323.

12. Cassagne, T.; Busschaert, F. Experience with duplex stainless steels in oil and gas production, Duplex 2007. In Proceedings of the Conference, Stainless Steel World, Grado, Italy, 17-20 June 2007.

13. Olsson, J.; Snis, M. Duplex-A new generation of stainless steels for desalination plants. Desalination 2007, 205, 104-113. [CrossRef]

14. Practical Guidelines for Fabrication of Duplex Stainless Steels; International Molybdenium Association: London, UK, 2009.

15. Available online: https://stainless.nipponsteel.com/en/campaigns/duplex (accessed on 10 March 2020).

16. Stradomski, Z. Mikrostruktura w Zagadnieniach Zużycia Staliw Trudnościeralnych; The Publishing House of the Faculty of Production Engineering and Materials Technology of the Czestochowa University of Technology: Czestochowa, Poland, 2010.

17. Stradomski, G.; Stradomski, Z.; Denis-Brewczyńska, D. The change of solidification mechanizm of ferritic-Austenitic cast steel. J. Achiev. Mater. Manuf. Eng. 2014, 63, 58-64.

18. Chih-Chun, H.; Dong-Yih, L.; Weite, W. Precipitation behavior of $\sigma$ phase in 19Cr-9Ni-2Mn and 18Cr-0.75Si stainless steels hot-rolled at $800{ }^{\circ} \mathrm{C}$ with various reduction ratios. Mater. Sci. Eng. A 2007, 467, 181-189.

19. Tavares, T.B.; Rodrigues, D.G.; Santos, D.B. Effect of Warm Rolling and Annealing on Microstructure, Texture, and Mechanical Properties of a 2205 Duplex Stainless Steel. Steel Res. Int. 2020, 3, 2019. [CrossRef]

20. Padilha, A.F.; Plaut, R.L.; Rios, P.R. Stainless steels heat treatment, Totten GE. In Steel Heat Treatment Handbook, 2nd ed.; Boca Raton. CRC Press: Boca Raton, FL, USA, 2007; pp. 695-739.

21. Miodownik, A.P.; Saunders, N. Modelling of materials properties in duplex stainless steels. Mater. Sci. Technol. 2002, 18, 861-868. [CrossRef]

22. Charles, J. Super Duplex Stainless Steels-Structure and Properties. In Proceedings of the Duplex Stainless Steels '91, Les Editions de Physique, F-91944 Les Ulis Cedex, Bourgogne, France, 28-30 October 1991; pp. 3-48.

23. Gajewski, M. Przemiany Strukturalne w Stalach i Staliwach Stosowanych w Energetyce oraz ich wptyw na Mechanizmy Pękania i Korozji, Monografia; Politechnika Świętokrzyska: Kielce, Poland, 2003.

24. Gunn, R. Duplex Stainless Steels-Microstructure, Properties and Applications; Woodhead Publishing: Cambridge, UK, 1997.

25. Rosso, M.; Peter, I.; Suani, D. About heat treatment and properties of Duplex Stainless Steels. J. Achiev. Mater. Manuf. Eng. 2013, 59, 30-36.

26. Gajewski, M. Wysokostopowe staliwa Cr-Ni-Cu utwardzane wydzieleniowo. Inżynieria Materiałowa 1988, 2, $35-41$.

27. Stradomski, G.; Soiński, M.S.; Nowak, K.; Szarek, A. The assessment of tendency to develop hot cracks in the duplex casts. Steel Res. Int. Spec. Ed. Met. Form. 2012, 1231-1234.

28. Karlsson, L. Intermetallic phase in duplex stainless steels and weld metals metallurgy, influence on properties and welding aspects. Weld. World 1999, 43, 20-40.

29. Michalska, J.; Sozańska, M. Qualitative and quantitative analysis of $\sigma$ and $\chi$ phases in 2205 duplex stainless steel. Mater. Charact. 2006, 56, 355-362. [CrossRef]

30. Shek, C.H.; Li, D.; Wong, K.; Lai, J.K.L. Creep properties of aged duplex stainless steels containing $\sigma$ phase. Mater. Sci. Eng. A 1999, 266, 30-36. [CrossRef]

31. Stradomski, G.; Nadolski, M.; Zyska, A.; Kania, B.; Rydz, D. Physical and numerical modeling of duplex cast steel thin-walled castings. Arch. Metall. Mater. 2019, 64, 1449-1456.

32. Llewellyn, D.T.; Hudd, R.C. Steels: Metallurgy and Applications, 3rd ed.; Butterworth-Heinemann: Oxford, UK, 1998.

33. Banaś, J.M.; Mazurkiewicz, A. The effect of copper on passivity and corrosion behavior of ferritic and ferritic-austenitic stainless steels. Mater. Sci. Eng. A 2000, 277, 183-191. 
34. Stradomska, J.; Stachura, S.; Stradomski, Z.; Soiński, M.S. The influence of copper on the microstructure and selected parameters of duplex cast steel. Arch. Foundry Eng. 2009, 9, 87-90.

35. De Lima, H.M.L.F.; Tavares, S.S.M.; Martins, M.; Araújo, W.S. The effect of copper addition on the corrosion resistance of cast duplex stainless steel. J. Mater. Res. Technol. 2019, 8, 2107-2119. [CrossRef]

(C) 2020 by the authors. Licensee MDPI, Basel, Switzerland. This article is an open access article distributed under the terms and conditions of the Creative Commons Attribution (CC BY) license (http://creativecommons.org/licenses/by/4.0/). 